\title{
Acceptability, predictors and attitudes of Canadian women in labour toward point-of-care HIV testing at a single labour and delivery unit
}

\author{
Salikah Iqbal MD ${ }^{1}$, Leanne R De Souza MSc², Mark H Yudin MD MSc ${ }^{1,2}$
}

\begin{abstract}
S Iqbal, LR De Souza, MH Yudin. Acceptability, predictors and attitudes of Canadian women in labour toward point-of-care HIV testing at a single labour and delivery unit. Can J Infect Dis Med Microbiol 2014;25(4):201-206.
\end{abstract}

OBJECTIVE: To assess attitudes and opinions surrounding point-ofcare HIV testing among Canadian women, and to determine predictors for acceptance of testing.

METHODS: A survey assessing acceptability and attitudes toward rapid HIV testing was distributed on the labour and delivery unit in an academic hospital (St Michael's Hospital) in Toronto, Ontario, in 2011. Information collected included demographic data, health and pregnancy history, willingness to undergo rapid HIV testing while in labour and barriers to testing.

RESULTS: Responses in 92 completed questionnaires were analyzed. The mean age of respondents was 32 years and all were HIV negative. Twelve percent of patients reported having at least one risk factor for HIV transmission. The study showed that only $59 \%$ of women were willing to be tested at the time of survey completion, and these women stated that they would accept saliva, urine or serum testing. If found to be positive, 96\% would accept antiretroviral treatment and 94\% would formula feed their infants. Of the $41 \%$ who were not willing to be tested, their reasons for refusal included "don't want to know" (39\%) and being in "too much labour pain" (29\%). Regardless of willingness to be tested, the most frequently cited barriers to testing were social stigma (64\%) and reaction from partners (69\%).

CONCLUSIONS: Canadian women in labour were willing to undergo rapid HIV testing via urine, saliva or serum. If found to be positive, women were willing to undergo treatment and to formula feed to prevent mother-to-child transmission of HIV.

Key Words: HIV; Labour; Point-of-care testing

$A$ significant proportion of individuals infected with HIV are $\mathrm{A}_{\text {women of reproductive age (15 to } 44 \text { years of age). Pregnant }}$ HIV-positive women are at risk of transmitting the virus to their infants (1). In 2010, approximately 220 infants were born to HIVpositive mothers in Canada (2). Research suggests that most perinatal transmission occurs during the intrapartum period, with estimates as high as $60 \%$ to $75 \%$ (3). Antiretroviral therapy administered during pregnancy, in labour and in the neonatal period reduces the rate of mother-to-child transmission (MTCT) by two-thirds. The Pediatric AIDS Clinical Trial Group 076 study found that intrapartum zidovudine alone reduced the transmission rate by one-third (4). Despite guidelines from the Society of Obstetricians and Gynecologists of Canada (5) and the Canadian Paediatric Society (3) to recommend universal antenatal HIV testing, some women remain unaware of their HIV status before delivery (6). Prenatal HIV testing rates vary among

\author{
L'acceptabilité, les prédicteurs et les attitudes des \\ femmes canadiennes en travail vis-à-vis du \\ dépistage du VIH dans une unité de travail et \\ d'accouchement
}

OBJECTIF : Évaluer les attitudes et les opinions des femmes canadiennes au sujet du dépistage du VIH au point de service et en déterminer les prédicteurs d'acceptation.

MÉTHODOLOGIE : En 2011, un sondage sur l'acceptabilité et les attitudes entourant un test de dépistage rapide du VIH a été distribué à l'unité de travail et d'accouchement d'un hôpital universitaire (St Michael's Hospital) de Toronto, en Ontario. Les chercheurs y ont colligé des données démographiques, les antécédents de santé et de grossesse, la volonté de subir un test de dépistage rapide du VIH pendant le travail et les obstacles à ce test.

RÉSULTATS : Les chercheurs ont analysé les réponses des 92 questionnaires remplis. Les répondantes, toutes séronégatives au VIH, avaient un âge moyen de 32 ans. Parmi elles, $12 \%$ ont déclaré présenter au moins un facteur de risque de transmission du VIH. Seulement 59 \% étaient prêtes à subir le test au moment de remplir le sondage. Elles ont indiqué qu'elles accepteraient un test par la salive, l'urine ou le sérum. Si les résultats étaient positifs, $96 \%$ accepteraient un traitement antirétroviral et $94 \%$ nourriraient leur nourrisson à l'aide de préparations lactées. Parmi les $41 \%$ qui n'étaient pas prêtes à subir le test, les raisons du refus incluaient « je ne veux pas le savoir » (39\%) et «trop de douleur causée par l'accouchement » (29\%). Quelle que soit la volonté de subir le test, les obstacles les plus cités étaient l'opprobre social (64\%) et la réaction des partenaires (69\%). CONCLUSIONS : Les femmes canadiennes en travail étaient prêtes à subir un dépistage rapide du VIH par l'urine, la salive ou le sérum. S'il était positif, les femmes étaient prêtes à se faire traiter et à nourrir leur nourrisson à l'aide de préparations lactées pour éviter de transmettre le VIH à leur enfant.

provinces and territories in Canada. For example, Ontario screens pregnant women in an opt-in fashion. In general, $30 \%$ of HIV-positive Canadians are unaware that they are infected (7).

The Public Health Agency of Canada approved a rapid HIV test for use in point-of-care (POC) settings in 2006 (8). The Centers for Disease Control and Prevention (Georgia, USA) (9) and American College of Obstetricians and Gynecologists (10) recommend rapid HIV testing for pregnant women in labour with no prenatal care or record of previous HIV testing during pregnancy. Although rapid HIV testing in labour is the standard of care in the United States, in Canada there are only a few hospitals with labour and delivery (LD) units that provide rapid HIV testing in POC settings. A recent study in Alberta conducted rapid HIV testing in various acute care settings; 1737 patients were tested and $875(50.3 \%)$ were pregnant women. Twenty-five (1.4\%) samples were found to be positive; however, no samples from pregnant women were

${ }^{1}$ Department of Obstetrics and Gynecology, University of Toronto; ${ }^{2}$ Department of Obstetrics and Gynecology, St Michael's Hospital, Toronto, Ontario

Correspondence: Dr Salikah Iqbal, Department of Obstetrics and Gynecology, University of Toronto, 92 College Street, Toronto, Ontario M5G 1L4. Telephone 416-529-9615, fax 416-978-8350, e-mail salikah.iqbal@utoronto.ca

OPEN $\bigcirc$ ACCESS

This open-access article is distributed under the terms of the Creative Commons Attribution Non-Commercial License (CC BY-NC) (http:// creativecommons.org/licenses/by-nc/4.0/), which permits reuse, distribution and reproduction of the article, provided that the original work is properly cited and the reuse is restricted to noncommercial purposes. For commercial reuse, contact support@pulsus.com 
TABLE 1

\section{Patient characteristics}

\begin{tabular}{|c|c|c|c|}
\hline \multirow[b]{2}{*}{ Characteristic } & \multicolumn{2}{|c|}{ Patient willing to be tested } & \multirow[b]{2}{*}{$\mathbf{P}$} \\
\hline & No & Yes & \\
\hline Age, years, mean \pm SD & $33.2 \pm 4.7$ & $30.8 \pm 4.2$ & \\
\hline Born in Canada & $31(77)$ & $9(23)$ & \\
\hline Born outside of Canada & $20(42)$ & $28(58)$ & 0.002 \\
\hline \multicolumn{4}{|l|}{ Race, $n$} \\
\hline White & 29 & 14 & 0.11 \\
\hline Aboriginal & 1 & 0 & \\
\hline Middle Eastern & 3 & 3 & 0.64 \\
\hline Black & 4 & 3 & 0.92 \\
\hline Asian & 14 & 7 & 0.007 \\
\hline Hispanic & 1 & 1 & 0.79 \\
\hline South East Asian & 7 & 3 & 0.45 \\
\hline \multicolumn{4}{|l|}{ Marital status } \\
\hline Single/separated/divorced & $3(6)$ & $2(5)$ & \\
\hline Married & $40(75)$ & $29(81)$ & \\
\hline $\begin{array}{l}\text { Common law/partnered/living } \\
\text { together }\end{array}$ & $10(19)$ & $5(14)$ & \\
\hline \multicolumn{4}{|l|}{ Level of education } \\
\hline High school & $5(9)$ & $6(17)$ & \\
\hline \multicolumn{4}{|l|}{ College/university } \\
\hline Graduate & $28(53)$ & $23(64)$ & \\
\hline \multicolumn{4}{|l|}{ Postgraduate/ } \\
\hline professional graduate & $20(38)$ & $7(19)$ & \\
\hline \multicolumn{4}{|l|}{ Obstetrical care provider } \\
\hline Obstetrician & $46(51)$ & $30(33)$ & \\
\hline Family practice & $4(4)$ & $5(5)$ & \\
\hline Midwife & $2(2)$ & $2(2)$ & \\
\hline Visits, $n$, mean \pm SD & $12.6 \pm 4.1$ & $12.5 \pm 5.0$ & \\
\hline \multicolumn{4}{|l|}{ Parity, $\mathrm{n}$} \\
\hline Nulliparous & 17 & 23 & \\
\hline Multiparous & 33 & 19 & \\
\hline \multicolumn{4}{|l|}{ Awareness of HIV testing } \\
\hline In this pregnancy & $41(77)$ & $22(59)$ & \\
\hline Previously & $46(88)$ & $23(66)$ & \\
\hline
\end{tabular}

Data presented as $n(\%)$ unless otherwise indicated. Bold text indicates statistical significance

positive. This was believed to be due to the high rates of prenatal testing and referral of all positive women to an urban centre for care. The group found rapid testing of HIV in acute-care settings to be feasible, especially when results can impact immediately on patient care (11). There is some evidence from American studies that, if offered, women would accept rapid HIV testing in labour (12).

At our institution (St Michael's Hospital [SMH], Toronto, Ontario), women are routinely screened for HIV antenatally. However, many patients presenting in labour are from a population with specific risk factors for HIV infection such as recent immigration from an endemic country. Also, women with limited prenatal care are not aware of their status and may be in a category that puts them at risk for HIV. The primary objective of the present study was to determine the acceptability of rapid HIV testing to Canadian women in labour. The secondary objectives were to determine predictors for acceptability of rapid HIV testing, and attitudes and opinions surrounding HIV testing, particularly barriers/fears surrounding testing.

\section{METHODS}

Ethics approval was provided by the Research Ethics Board at SMH in advance of data collection (REB 10-331c).

A survey study of women in labour from July 2011 to September 2011 was conducted. The survey assessed attitudes and expectations toward rapid HIV testing and was compiled based on questions from the survey 'Women and HIV Testing in Canada: Access and Concerns', originally composed by the Canadian AIDS Society (13). Before study initiation, the survey was reviewed by the study authors, other physicians and LD nurses for content validity. Any questions perceived to be ambiguous were removed. Before distribution, the survey was piloted with health care providers, but not with the target population. Information collected included demographic data, health and pregnancy history, willingness to undergo rapid HIV testing while in labour and barriers to testing. The final version of the survey comprised 24 questions over six pages (Appendix 1).

The study was conducted at $\mathrm{SMH}$, an inner-city tertiary academic centre. The LD unit serves a multiethnic, socioeconomically varied population, with approximately 3000 births per year. All women presenting in labour during day-shift hours (08:00 to $17: 00)$ were approached by residents or nurses for participation in the study. Attempts were made to approach all women presenting in labour, providing they were not in extreme discomfort or being prepared for expedited delivery for medical reasons. Inclusion criteria were pregnant English-literate females presenting to the SMH LD unit beyond 34 weeks' gestation with one or more of the following signs of labour: ruptured membranes, regular contractions and cervical dilation.

The survey was completed either in triage or in one of the labour rooms. The returned survey was collected by a nurse or resident and stored in a closed box at the nursing station. HIV testing was not performed.

Sample size was not calculated for the present study. Completed surveys were collected and all data were compiled by one author (SI) and entered into an Excel spreadsheet (Microsoft Corporation, USA). Descriptive statistics were used to describe the study population. Statistical analyses were performed using SAS 9.3 (SAS Institute Inc, USA). The rate of willingness to accept POC HIV testing was defined as the proportion of women who stated that they would accept testing at the time of survey completion. Among women who refused to be tested at the time of survey completion, the reasons for refusal were tabulated to determine which were the most common. Fisher's exact and $\chi^{2}$ testing were used to compare responses between those willing and those unwilling to undergo testing.

\section{RESULTS}

During the study period, 153 questionnaires were distributed and 92 completed surveys were collected (60\% response rate).

Patient characteristics are presented in Table 1. Fifty-two percent of all patients were born outside of Canada, reflecting the multiethnic and diverse patient population. The majority of women were married $(68 \%)$ and educated beyond high school (89\%). Most of the women were cared for in their pregnancy by an obstetrician $(85 \%)$ or a family doctor (10\%). Most respondents had adequate care, with $42 \%$ of women reporting between 10 and 12 visits with their care provider. Twelve percent of patients reported having at least one risk factor for HIV transmission based on the survey questionnaire.

Seventy-one women (80\%) self-reported having ever been tested for HIV, and $71 \%$ were aware of having been tested during their current pregnancy. 99\% responded that they were HIV negative, with the remaining one respondent responding "I don't know" for her HIV status.

Fifty-nine percent of women were willing to be tested at the time of survey completion. Of those willing to be tested, the majority would accept any method of testing (Figure 1). Respondents born outside of Canada were significantly more likely to accept testing $(\mathrm{P}=0.002)$. Asian (Chinese, Japanese, Korean and Filipino) women were statistically significantly less likely to accept testing in labour $(\mathrm{P}=0.007)$. There were no significant differences in marital status, level of education and antenatal care provider (obstetrician, family physician or midwife) between those willing and those unwilling to be tested. If found to be positive, $96 \%$ of respondents would accept antiretroviral treatment and $94 \%$ would formula feed their infants.

Respondents who were not willing to undergo testing had significantly more concerns with regard to testing (Table 2). The top concerns in women unwilling to undergo testing included wanting to 


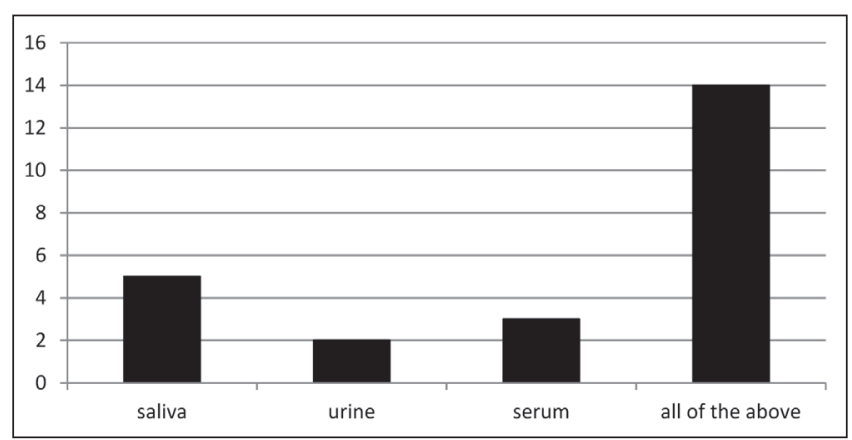

Figure 1) Acceptable methods of testing in individuals willing to be tested (percentage)

"know more about the benefits of early diagnosis" (75\% versus 39\% in those willing to be tested; $\mathrm{P}<0.0001$ ) and "length of wait time for results" (70\% versus 39\%; $\mathrm{P}<0.002)$. Other differences in concerns were the testing process itself $(67 \%$ versus $24 \% ; \mathrm{P}<0.001)$ and who would have access to results $(64 \%$ versus $24 \%$; $P<0.0002)$.

When answering survey questions about what would make the testing process easier, there were significant differences between the two groups. Relative to women who were willing to be tested, women who were not willing to undergo testing stated that providing more information about the testing process $(\mathrm{P}=0.007)$ and an individualized counselling approach $(\mathrm{P}=0.0068)$ would facilitate testing. Additionally, more women ( $74 \%$ versus $26 \%$; $\mathrm{P}=0.0031$ ) responded that a discussion surrounding preventing MTCT would make the process easier.

With respect to post-test counselling, women were asked what information they would want to know after testing. Women willing to undergo testing were significantly more likely to be interested in learning about HIV treatment options $(\mathrm{P}<0.0001)$, access to health care services $(P<0.0002)$ and the partner notification process $(P<0.0005)$ than those not willing to undergo testing. When asked with whom they would like to discuss the results of testing, the majority (84\%) of women chose a physician. Differences according to ethnicity were again observed in terms of who the respondent wanted to discuss the results with. The majority of respondents wanted to discuss a positive result with a physician (76\% Asian, $84 \%$ all ethnicities). However, a higher proportion of Asian patients expressed a desire to discuss a positive result with their family as well $(57 \%$ versus $38 \% ; \mathrm{P}<0.05)$.

Table 3 outlines barriers to testing in women not willing to be tested at the time of survey completion $(41 \%)$. Their prime reasons for refusal included "don't want to know" (39\%) and being in "too much labour pain" (29\%). Regardless of willingness to be tested, social stigma (64\%) and reaction from partners (69\%) were the most frequently cited barriers to testing by all respondents.

\section{DISCUSSION}

Our study showed that only 59\% of women in active labour on an LD unit were willing to undergo rapid HIV testing; however, if found to be HIV positive, the majority were willing to receive HIV treatment and to formula feed to reduce MTCT of HIV.

A previous study from our centre found that even among women who have received comprehensive prenatal care, up to one-third may not have their HIV status documented on the antenatal records, or their records may not be available (14). Thus, there may be a relevant opportunity for POC HIV testing in all women in labour. The MotherInfant Rapid Intervention at Delivery (MIRIAD) trial (13), conducted in the United States, was a prospective, multicentre trial that offered voluntary rapid HIV testing in $>7753$ women. The study found that $90 \%$ of women accepted testing, and an HIV infection rate of $0.7 \%$ was found in labouring women using POC testing.

Unlike the standard ELISA HIV test, which may take $24 \mathrm{~h}$ to $48 \mathrm{~h}$ to process, POC HIV tests yield results within $10 \mathrm{~min}$ to $20 \mathrm{~min}$, allowing time for effective treatments to be administered. The POC test has been shown to be equivalent in performance to laboratory
TABLE 2

Comparison of concerns before being tested for HIV

\begin{tabular}{|c|c|c|c|}
\hline & \multicolumn{2}{|c|}{ Patient willing to be tested } & \multirow[b]{2}{*}{$\mathbf{P}$} \\
\hline & No & Yes & \\
\hline The benefits of early diagnosis & $40(75)$ & $11(29)$ & $<0.0001$ \\
\hline The testing process & $36(67)$ & $9(24)$ & $<0.001$ \\
\hline $\begin{array}{l}\text { How long it takes for results to } \\
\text { come back }\end{array}$ & $37(70)$ & $11(29)$ & $<0.002$ \\
\hline HIV treatment options & $29(54)$ & $9(24)$ & 0.004 \\
\hline $\begin{array}{l}\text { Support services available in the } \\
\text { area }\end{array}$ & $24(45)$ & $7(19)$ & 0.01 \\
\hline The partner notification process & $27(51)$ & $6(16)$ & 0.0008 \\
\hline $\begin{array}{l}\text { Who will have access to the } \\
\text { results }\end{array}$ & $34(64)$ & $9(24)$ & 0.0002 \\
\hline
\end{tabular}

Data presented as $n(\%)$ unless otherwise indicated

TABLE 3

Reasons for refusal in individuals not willing to undergo testing

\begin{tabular}{ll}
\hline Reason cited & $\%$ \\
\hline Don't want to know & 39 \\
Too much labour pain & 29 \\
Fear of pain from testing & 18 \\
Fear of breach of confidentiality & 11 \\
Fear of partner's/family's/community's reaction & 11 \\
Fear of losing children & 7 \\
Fear of death & 7 \\
Other: already been tested in pregnancy & 3 \\
Fear of losing job/home & 2 \\
No time & 1 \\
\hline
\end{tabular}

HIV screening tests. A recent meta-analysis from a group in Montreal (Quebec) aimed to summarize the diagnostic accuracy of rapid HIV tests in pregnancy. Analyses of 17 studies suggested the overall sensitivity and specificity of blood-based rapid tests $(86.4 \%$ to $100 \%$ and $99.5 \%$ to $100 \%$, respectively). Oral rapid tests performed well, with a sensitivity of $75 \%$ to $100 \%$. The largest study (MIRIAD) used OraQuick (OraSure Technologies Inc, USA) and reported a high sensitivity and specificity (100\% and 99.9\%) (15).

Advantages of POC testing include faster results, wider access to HIV testing (ie, easier to deliver preliminary results to hard-to-reach high-risk populations) and the ability to make immediate decisions about initiating therapy. Disadvantages include the possibility of false positives. In a study conducted in Alberta (11), 25 of 1737 tests $(1.4 \%)$ were found to be positive. In this case, treatment would likely be provided, and post-test counselling taking place postpartum would be paramount in the management.

In addition to examining acceptance rates, we also explored patient characteristics that may be associated with accepting HIV testing. We found that being born outside of Canada was a predictor of acceptance. A recent Swedish study (16) found that, if offered a test by a health care provider, immigrant women would be willing to accept preventive health measures in the form of human papillomavirus vaccination. This study found that providing information in different languages and through different sources helps to increase uptake of programmes (16). Another study involving Vietnamese American immigrant women found increased Pap testing adherence if suggested by a friend, longer residency in the United States, having health insurance, and recommendation from a physician or nurse practitioner (17). It is possible that women born outside of Canada have more knowledge of or experience with HIV, and this may have translated into an increased acceptance of testing. Future work could focus on reasons for differential acceptance rates among immigrants originating 
from various regions of the world, and on influences toward increasing rates among Canadian-born women.

Our study also found that women of Asian background (Chinese, Japanese, Korean and Filipino) were less willing to accept testing. Of the 21 women reporting Asian background, only one was born outside of Canada and, thus, these were predominantly Canadian-born women. Other studies have also found differences in acceptance of HIV testing between different ethnic groups. A previous prospective study of pregnant women in our centre found Asian women were significantly less likely to accept routine HIV testing if given the option to opt out (18). Another study involving 1504 women with regular gynecological care found that Asian women were less likely to undergo routine HIV testing $(17.2 \%)$ compared with other races (19). Barriers to being tested in this demographic have also been explored in the emergency room setting among Asian men who have sex with men. Perception of not being at risk was the number one reason affecting testing behaviours (20). Future research should explore the reasons for this decreased acceptance of HIV testing among individuals of Asian ancestry.

With respect to women's concerns regarding testing, 39\% of women did "not want to know" their HIV status. Women who did not want to be tested also reported concerns around the testing process itself. These fears could be allayed by providing information to women about the noninvasive nature of urine or saliva testing, and also by discussing the benefits of early diagnosis and treatment in decreasing MTCT.

The ease with which POC testing can be performed presents some issues, particularly with regard to consent and counselling. Pre- and post-test counselling are particularly important with rapid POC testing, as with conventional testing, as recommended by the Public Health Agency of Canada (21). Women who completed our survey identified counselling and the provision of appropriate information about HIV results as important factors. Specifically regarding post-test counselling, women stated a desire to discuss prevention of transmission, information regarding treatment and the partner notification process. This information could be provided in the LD unit in various languages. Our respondents also stated a preference for discussing results with a physician in a private room, which could be ensured whenever a positive test result arose.

Several limitations to the present study should be acknowledged. Actual HIV testing was not performed and, thus, responses of participants were to a hypothetical scenario; future studies could explore this further. In addition, the present study had a small sample size and data were collected from a single-centre LD unit. The results may not be generalizable to all LD units. However, the feedback from the study does provide some insight, including the fact that on-call care providers may believe that they do not have the time to devote to pretest and post-test counselling. Further research investigating the opinions of care providers may reveal information about preparedness to discuss POC test results. Although we explored attitudes toward testing, it is unclear whether women would respond differently if they were to actually undergo testing, knowing that the nature of the test is that it is a preliminary and thus unconfirmed result. Our study sample also included a high proportion of women who received comprehensive prenatal care, were English literate and were at low risk for HIV. While $12 \%$ of our survey respondents had risk factors for HIV, most of these included a history of sexually transmitted infections, such as herpes and chlamydia, or recipients of blood transfusions. Therefore, our study did not include many women who would be considered high risk for HIV such as intravenous drug users, street sex workers and refugees from endemic areas.

The present study provides important information to LD professionals with regard to POC HIV testing. Although rapid HIV testing is recommended for pregnant women by both the Centers for Disease Control and Prevention and the American College of Obstetricians and Gynecologists, there are currently no synonymous Canadian recommendations. To our knowledge, the present study was the first to examine the acceptability of rapid HIV testing in a POC setting in Canada.

\section{CONCLUSION}

The present study found that Canadian women in labour would be willing to undergo noninvasive rapid HIV testing via urine, saliva or serum. Ethnicity and place of birth were found to influence acceptance of rapid HIV testing. If found to be HIV-positive, women were willing to undergo treatment as well as to formula feed their infants to prevent MTCT of HIV.

ACKNOWLEDGEMENTS: The authors thank Rosane Nisenbaum for assistance with statistical analysis. The publication of this manuscript was supported by a CIHR Emerging Team Grant: 'Maternal Health - From Preconception to the Empty Nest', awarded to the Interdisciplinary HIV Pregnancy Research Group: <http://www.researchnet-recherchenet.ca/ rnr16/viewOpportunityDetails.do?prog=1012\&language $=E \&$ fodAgency $=$ $\mathrm{CIHR} \&$ view $=$ browseArchive\& browse $\mathrm{Arc}=$ true $>$.

\section{APPENDIX 1}

Dear Patient,

This study is a survey designed to help understand the attitudes of our patients in labour towards HIV testing at St Michael's Hospital. This is a resident study conducted by Dr Salikah Iqbal under the supervision of Dr Yudin at St Michael's Hospital. It should take less than 10 minutes to complete the survey.

The answers to the survey will help us to give the best care to prevent passing HIV from a mother to a baby. The results of this study may be presented at conferences, seminars or other public forums, and published in journals, but your own personal information will be kept private.

Your participation is completely voluntary, and in no way will affect your medical care. Your name is not required and no one will be able to identify you from your answers to the survey. If there are any questions that you do not wish to answer, please feel free to go on to the next question. You also have the right to stop answering questions at any time.

If you complete and submit this survey, it will be assumed that you have agreed to participate in this study.

If you have any questions about the study or the survey content, please contact the principal investigator, Dr Salikah Iqbal, a resident in the Department of OBGYN at the University of Toronto 416-380-5821 or at salikah.iqbal@utoronto.ca

If you have any concerns about your treatment or rights as a research participant, you may contact Dr Bob Hyland, Chair, Research Ethics Board at St Michael's Hospital at 416-864-6060 Ext. 2557 during business hours.

Please keep a copy of this document for your records.

Thank you for your time.

Dr Mark Yudin, Principal Investigator; Dr Salikah Iqbal, University of Toronto; Leanne DeSouza MSc, Co-Investigator

Department of Obstetrics\& Gynecology, St Michael's Hospital, Toronto, On, (416) 864-6060 × 8047

You are being asked to participate in a survey study about the attitudes of patients towards HIV testing at St Michael's Hospital. The survey will take about 10 minutes to complete. As our patient, we value your opinion about HIV testing and expectations of HIV counselling. This information will help in providing the best care in preventing HIV transmission. Completion of this survey is considered your consent to participate. This survey is anonymous. Your responses are confidential. Your participation is completely voluntary, and in no way will affect your medical care. If there are any questions that you do not wish to answer, please feel free to go on to the next question.

\section{DEMOGRAPHIC INFORMATION:}

How old are you? $\quad$ What is your marital status? (Please check one):
1. $\quad$ Single
$\square \quad$ Partnered but not living together
$\square \quad$ Married
$\square \quad$ Common Law/Living Together


Separated/Divorced

Widowed

2. What is the ethnic background you most identify with?

(Please check any that apply):

Aboriginal (Inuit, Metis, North American Indian)

White (Caucasian)

Middle Eastern (e.g., Armenian, Egyptian, Iranian,

Lebanese, Moroccan)

Black (e.g., African, Caribbean)

Asian (Chinese, Japanese, Korean, Filipino)

Hispanic

South Asian (Indian, Pakistani, Bangladeshi)

Other, please specify:

3. Which of the following describes your residency status?

(please check one):

Born in Canada

Immigrant

Refugee

Visitor

4. What is the highest level of education that you have completed? (Please check one):

High school

College/university graduate

Post graduate/Professional degree

None of the above

5. Which of the following describes your current residence

(Please check one):

Own home/ condo/ duplex etc.

Renting

Living with family or friends

Living in a shelter

Homeless

Other

\section{PREGNANCY INFORMATION:}

1. Who is your primary pregnancy caregiver? (Please check one):

Midwife

Family doctor

Obstetrician

I don't have a pregnancy caregiver

2. How many visits have you had with your pregnancy caregiver?

\section{HEALTH HISTORY INFORMATION:}

1. How many pregnancies have you had in total? (Including miscarriages):

2. How many babies born to you in total? How many living children do you have?

3. How many vaginal births have you had?__ How many cesarean sections have you had?

4. Do you have a history of any of the following? (Check all that apply)

Sexually transmitted infection (for example, gonorrhea, chlamydia, HPV or syphilis?)

Hepatitis Type B or Type C?

Have you ever received a blood transfusion?

Have you ever used drugs with needles outside of a hospital? (e.g. heroin, cocaine)

5. Have you ever been tested for HIV (Please check one) Yes

No

Do not know

6. Have you been tested for HIV in this pregnancy? (Please check one)

Yes

No
7. Are you HIV-positive (Please check one)

Yes

No

Do not know

8. Have you ever been treated for HIV (Please check one)

Yes

No

\section{ATTITUDES TOWARD HIV TESTING:}

1. Would you be willing to be tested for HIV right now? (Please check one)

Yes

No

2. What kind of information would you want to know before being tested for HIV (check all that apply)?

The benefits of early diagnosis

The testing process

How long it takes for results to come back

HIV treatment options

Support services available in the area

The partner notification process

Who will have access to the results

Other (please specify)

3. What kind of information would you want to know after testing if positive for HIV? (check all that apply)

HIV treatment options

Support services available in the area

Access to appropriate health care services

Written information about HIV/AIDS

The partner notification process

Other (please specify)

4. What would make the HIV testing easier for you? (check all that apply)

A non-judgmental attitude from testing providers

Offering more information about the testing process

Offering more information about treatment options

Offering more information about services available in the area

Discussing the fears associated with HIV testing

Discussing the partner notification process

Discussing the prevention of mother-to-child transmission

An individualized counselling approach

A private room for counselling

Other (please specify)

5. Which type of testing would you be willing to undergo? (you may check more than one)

Saliva

Urine

Blood

All of the above

6. If you were found to have a positive result - would you accept intravenous treatment for HIV during labour if there is a chance it would decrease HIV transmission to your baby? (Please check one)

Yes

No

7. If you were to have a positive result - would you be willing to formula feed only if there is a chance it would decrease HIV transmission to your baby? (Please check one)

Yes

No

8. If you were found to have a positive result - who would you want to discuss it with? (check all that apply)

Doctor

Nurse

Social worker

Counselor

Family/friends 
$\square \quad$ Other (please specify)

9. If you would not be willing to be tested, which of the following describe your reasons for refusal? (check all that apply)

Too much labour pain

Fear of pain from testing

No time

Don't want to know

Fear of breach of confidentiality

Fear of partner's/family's/community's reaction

Fear of losing children

Fear of death

Fear of losing job

\section{REFERENCES}

1. Public Health Agency of Canada. National HIV Prevalence and Incidence Estimates in Canada for 2008. <www.phac-aspc.gc.ca/aidssida/publication/epi/2010/1-eng.php> (Accessed August 12, 2012).

2. Canadian Perinatal HIV Surveillance Program. 2011. <www.phacaspc.gc.ca/aids-sida/publication/survreport/2012/dec/index-eng.php> (Accessed August 12, 2012).

3. JL Robinson; Canadian Paediatric Society, Infectious Diseases and Immunization Committee. Testing for HIV infection in pregnancy. Paediatr Child Health 2008;13:221-4.

4. Sperling RS, Shapiro DE, McSherry GD, et al. Safety of the maternal-infant zidovudine regimen utilized in the Pediatric AIDS Clinical Trial Group 076 Study. AIDS 1998;12:1805-13.

5. Society of Obstetricians and Gynecologists of Canada. HIV Screening in Pregnancy SOGC Clinical Practice Guideline Number $185,2006$.

6. Public Health Agency of Canada. HIV/AIDS Epi Updates - July 2010. Ottawa. <www.phac-aspc.gc.ca/aids-sida/publication/ epi/2010/7-eng.php > (Accessed November 26, 2013).

7. Public Health Agency of Canada. HIV and AIDS in Canada. Surveillance Report to December 31, 2008 . Ottawa: Surveillance and Risk Assessment Division, Centre for Communicable Diseases and Infection Control, Public Health Agency of Canada, 2009. $<$ www.phac-aspc.gc.ca/aids sida/publication/survreport/2007/ surveillance_2007_10-eng.php> (Accessed August 12, 2012).

8. CNW Telebec. Health Canada approves new MedMira rapid HIV test. October 21, 2004. <www.cnw.ca/fr/releases/archive/ October2004/21/c3182.html> (Accessed August 12, 2012).

9. Rapid HIV antibody testing during labor and delivery for women of unknown HIV status. A practical guide and model protocol. Centers for Disease Control and Prevention. January 30, 2004.

10. American College of Obstetricians and Gynecologists. Prenatal and perinatal human immunodeficiency virus testing: Expanded recommendations. ACOG Committee Opinion 304. Washington DC: ACOG, 2004.

11. Lee BE, Plitt S, Fenton J, Preiksaitis JK, Singh AE. Rapid HIV Tests in acute care settings in an area of low HIV prevalence in Canada. J Virol Methods 2011;172:66-71.

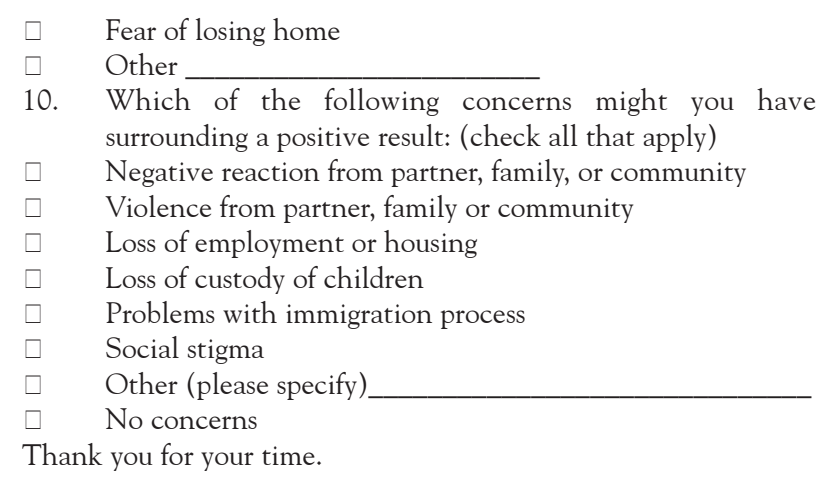

12. Bulterys M, Jamieson D, O'Sullivan M, et al. Rapid HIV-1 testing during labor: A multicenter study. JAMA 2004;292:219-23.

13. Wertheimer S. Women and HIV testing in Canada: Barriers and recommendations as identified by service providers: A summary of key research findings. Ottawa: Canadian AIDS Society, 2011.

14. Yudin, M, Barbara A, Guenter D, Shaul R, Remis R, King S. Medical records and women's self-report are not reliable sources for determining whether prenatal HIV testing was done. J Obstet Gynaecol Can 2006;28:867-72.

15. Pai NP, Tulsky JP, Cohan D, et al. Rapid point-of-care HIV testing in pregnant women: A systematic review and meta-analysis. Trop Med Int Health 2007;12:162-73.

16. Grandahl M, Tydén T, Gottvall M, Westerling R, Oscarsson M. Immigrant women's experiences and views on the prevention of cervical cancer: A qualitative study. Health Expectations 2012 (In Press).

17. Nguyen-Truong CK, Lee-Lin F, Leo MC, et al. A community-based participatory research approach to understanding Pap testing adherence among Vietnamese American immigrants. J Obstet Gynecol Neonat Nurs 2012;41:E26-E40.

18. Yudin M, Moravac C, Shah RS. Influence of an "Opt-Out" test strategy and patient factors on human immunodeficiency virus screening in pregnancy. Obstet Gynecol 2007;110:81-6.

19. Hahm HC, Song IH, Ozonoff A, Sassani JC. HIV testing among sexually experienced Asian and Pacific Islander young women association with routine gynecologic care. Womens Health Issues 2009;19:279-88 (Erratum in 2009;19:352).

20. Wong FY, Nehl EJ, Han JJ, et al; MATH Study Consortium. HIV testing and management: Findings from a national sample of Asian/ Pacific islander men who have sex with men. Public Health Rep 2012;127:186-94.

21. Public Health Agency of Canada. HIV Screening and Testing Guide, 2013. <www.phac-aspc.gc.ca/aids-sida/guide/hivstg-vihgddeng.php> (Accessed November 26, 2013). 


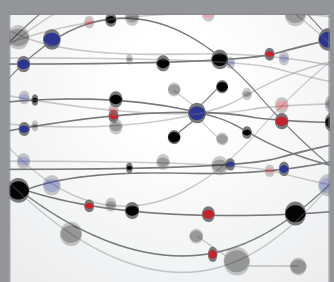

The Scientific World Journal
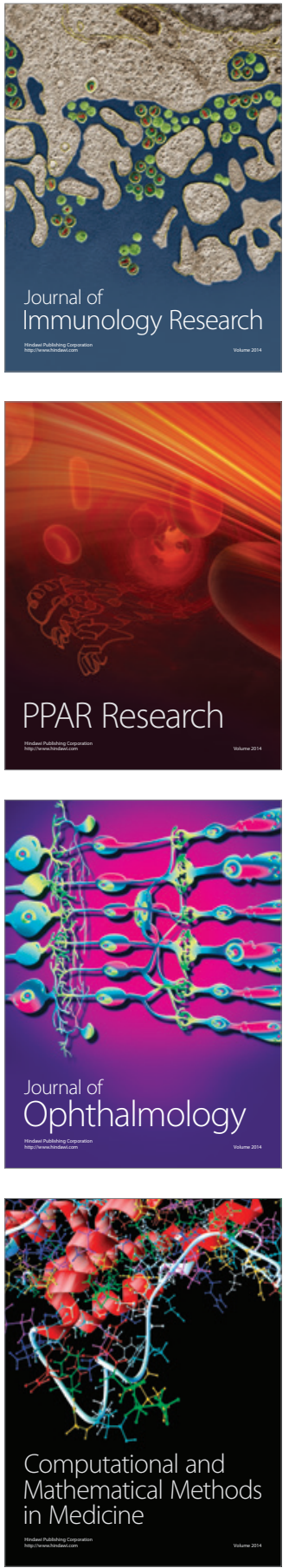

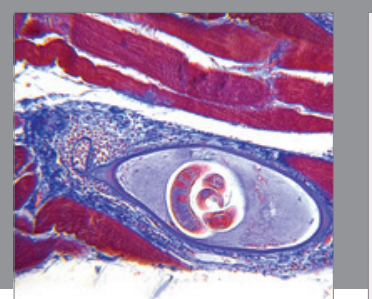

Gastroenterology Research and Practice

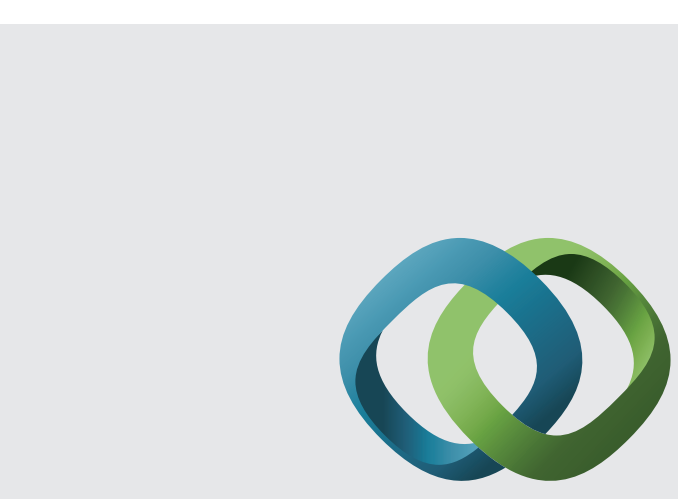

\section{Hindawi}

Submit your manuscripts at

http://www.hindawi.com
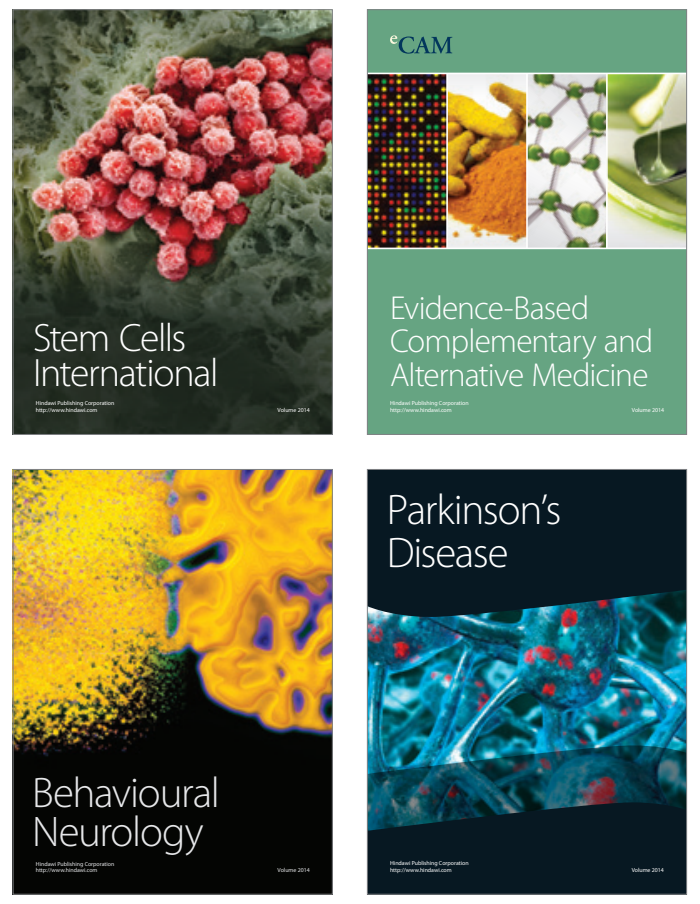
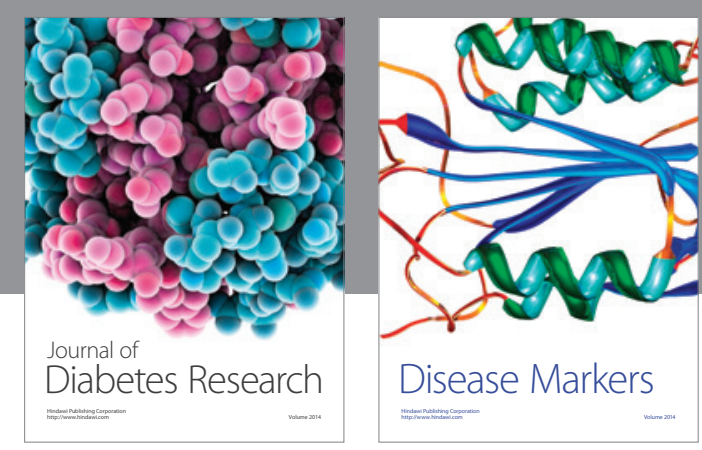

Disease Markers
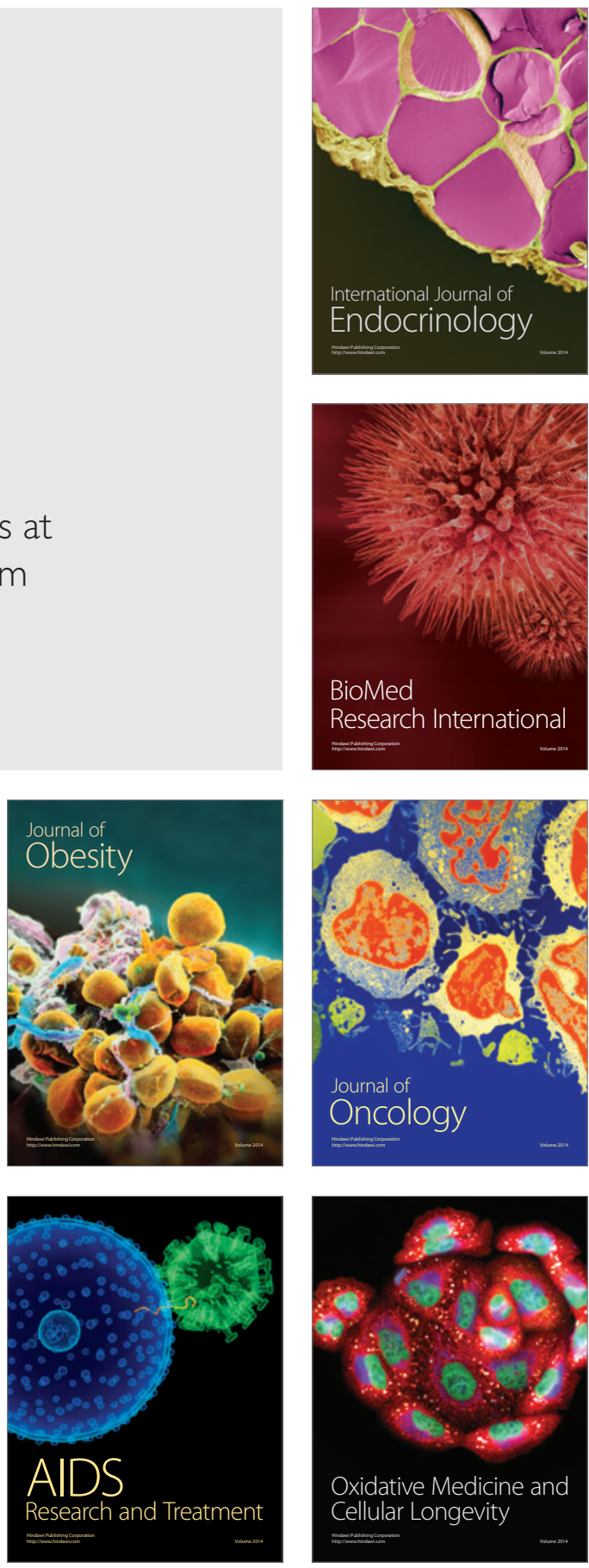